ks. Stanisław Wronka

\title{
Jan Paweł II - człowiek dobry
}

Wielkość drzewa uwidacznia się w pełni dopiero po jego ścięciu, kiedy leży powalone na ziemi. Wtedy można naprawdę ocenić jego wysokość, masywność pnia i rozłożystość konarów, a także zobaczyć jego wnętrze - czy jest zdrowe, gęste, czy też rzadkie, zbutwiałe lub puste. Wtedy też uświadamiamy sobie, często ze zdumieniem, jak wielką przestrzeń zajmowało w znanym nam krajobrazie; potrzeba wielu lat, by nowe drzewa mogły znów zapełnić powstałą po nim pustkę. Podobnie jest z człowiekiem. Śmierć odkrywa bezlitośnie prawdę o nim, o jego wielkości lub małości. Jest ostateczną próbą człowieka. W jej obliczu nie można niczego udawać. Starożytni radzili, by z definitywną oceną człowieka poczekać do jego śmierci. Dopiero po niej widać, kim ktoś był naprawdę i jaką przestrzeń zajmował w świecie, w życiu innych.

Mądrość tych spostrzeżeń sprawdza się szczególnie wyraziście w odniesieniu do Jana Pawła II. Jego śmierć objawiła ostatecznie wielkość naszego Papieża, potwierdziła to, co wielu dostrzegało już za jego życia, zwłaszcza ci, którzy mieli szczęście poznać go bliżej. To „drzewo” było rzeczywiście ogromne i do rdzenia zdrowe, jak pokazał to nam jego testament. Pustka, która się po nim otwarła, wydaje się nie do ogarnięcia, rozciąga się na każde niemal serce i na cały świat.

Zrzucenie powłoki cielesnej odsłoniło bogactwo i piękno spełnionego człowieczeństwa, utkanego w całości z prawdy, wolności, miłości i zawierzenia. W tkaninę tego człowieczeństwa nie wplotła się żadna nić tandetna czy fałszywa. Ojciec Święty żył wielkimi wartościami w sposób radykalny i bezkompromisowy. Był cały (totus) otwarty na nie, bronił ich w sobie i wokół siebie, realizował je odważnie i niestrudzenie. Odwaga Papieża zdumiewała wielu. Nie bał się krytyk, odrzucenia, a nawet kul, podejmując nieustraszenie swoją misje po zamachu. Rzucał wyzwanie zarówno komunizmowi, jak i nieludzkim formom kapitalizmu (George W. Bush), występował przeciwko moralnemu relatywizmowi, stając zawsze po stronie człowieka, broniąc jego godności. Zdaniem francuskiego dziennika 
„Le Figaro” Ojciec Święty przypomniał światu właśnie przede wszystkim cnotę odwagi, dzisiaj tak często zapomnianą.

Bezkompromisowość w walce o podstawowe wartości umiał Jan Paweł II łączyć z łagodnością i szacunkiem wobec innych. Papież walczył nie raniąc ludzi, poprzez własne świadectwo przybliżał im te wartości, pomagał przekonać się do nich i na nie otworzyć. Nie stosował siły w żadnej postaci, chciał, by wartości same przemawiały i zdobywały własną siłą. Na okrutną przemoc zamachowcy odpowiedział przebaczeniem. Nie odwoływał się nawet za często do nakazów i zakazów, starał się raczej pokazywać, że można żyć inaczej, sensowniej, piękniej. A robił to w taki sposób, że przy nim rzeczywiście nie wypadało postępować źle, żyć bezmyślnie. Kiedy musiał kogoś upomnieć, czynił to z bólem, podkreślając jednocześnie jego wartość pomimo zła, które popełnił. Do podchmielonego górala mówił: Dobry z ciebie chłop, ale nie pij! Ten charakterystyczny dla Papieża styl i sposób oddziaływania - styl Wojtyłowy, jak nazywa go ks. Mieczysław Maliński - z pozoru skazany na przegraną, okazywał się na dłuższą metę bardzo skuteczny.

Łączenie radykalizmu z łagodnością jest bardzo trudną sztuką. Taka synteza udaje się tylko nielicznym, świadczy o moralnym geniuszu człowieka. Ojciec Święty umiał łączyć ze sobą przeciwieństwa zdawałoby się nie do pogodzenia. A rozpiętość jego życia była niezwykle rozległa, obejmowała wszystkie autentyczne doświadczenia ludzkie: pracę i studia, sztukę i zaangażowanie społeczne, kontakty z ludźmi, odpoczynek na łonie natury i sport. Potrafił ogarnąć to wszystko i połączyć w jedną, harmonijną całość. Obdarowany bogato różnymi talentami, nie zakopał żadnego z nich, ale rozwinął i wykorzystał dla siebie i drugich. Dzisiaj nikt nie żałuje, że nie został aktorem, jak zamierzał na początku.

Fundamentem tej okazałej i pięknej budowli człowieczeństwa Ojca Świętego była niewątpliwie jego wiara. Nie tylko nie zdławiła ona w nim żadnej naturalnej wartości, ale oczyściła je i ubogaciła. Bez oparcia w Bogu i całkowitego zawierzenia Mu budowla człowieczeństwa Papieża nie byłaby ani tak ogromna, ani tak kształtna. Jego osobowość i życie dowodzą, że Ewangelia zawiera prawdziwą antropologię, w świetle której człowiek może osiągnąć pełnię. Jan Paweł II zadaje kłam wszystkim innym antropologiom, nie tylko teoretycznie w swoich dziełach, ale także praktycznie swoim życiem. Koncepcje ateistyczne, materialistyczne, konsumpcjonistyczne nie dają pełnego obrazu człowieka, zatrzymują się na jego powierzchni, dotykają tylko jakiegoś aspektu, a czasem zafałszowują zupełnie ten obraz, prowadząc do redukcji człowieka, a w skrajnych wypadkach do jego zniszczenia. Wiara pozwala uchwycić całą ludzką rzeczywistość i zintegrować różne jej elementy, łącznie z cierpieniem i śmiercią. Osobisty lekarz 
Papieża prof. Renato Buzzonetti wyznał na łamach włoskiego dziennika „La Repubblica”, że Jan Paweł II umierał powoli, w bólu i cierpieniu, które znosił z wielką godnością, że jego wiara pokonała ból, podobnie jak to było w wypadku męki Chrystusa. Poza wiarą cierpienie i śmierć są absurdem i dlatego nie do zniesienia. Wyraził to dosadnie przed laty pewien włoski artysta, który umierał zbuntowany i rozgoryczony na Boga i na cały świat ze słowami: Życie jest cudowne, ale śmierć budzi wstręt ( $f a$ schifo). Ojciec Święty przyjął spokojnie także śmierć - kiedyś swoich najbliższych, a teraz własną - jako część ludzkiego losu, wyszedł na jej spotkanie, wszedł w jej ciemność, wierząc, że nie jest to ostateczny koniec, ale przejście do królestwa światła. Bogu powierzył swoje życie i posługę aż do ostatnich dni, nie martwiąc się na zapas, jak podoła złożonym na niego obowiązkom, gdy siły będą go opuszczały. Bóg sprawił, że do ostatnich chwil mógł spełniać swą posługę, i to z jak niezwykłym skutkiem! Religia pozwala stawić czoło wszystkim wyzwaniom, które niesie życie, znaleźć w każdej sytuacji właściwe rozwiązanie, kształtuje ludzi odpowiedzialnych i mocnych. Nie jest opium dla ludu czy wyrazem resentymentu nieudaczników życiowych względem ludzi sukcesu. Papież pokazał na własnym przykładzie, czym może być wiara dla człowieka i całych narodów, jak wielką inspiracją i siłą się staje, gdy jest dojrzała i konsekwentna.

Osobista wielkość Papieża nie odcinała go od ludzi, ale przybliżała do nich. Prawdziwe człowieczeństwo rodzi się bowiem w relacjach z drugimi, łączy ludzi, buduje wspólnotę. Indywidualista, egoista nie jest pełnym człowiekiem. Również do Boga dochodzi się poprzez ludzi i wraz z nimi. Papież umiał gromadzić i jednoczyć innych wokół siebie, ostatecznie wokół najwyższych wartości, którymi starał się żyć, wokół Boga. Nie były to przelotne spotkania, ale trwałe więzi, którym pozostawał wierny, nawet jeśli czasem druga strona zawodziła. Wystarczy pomyśleć, że do ostatnich dni utrzymywał listowny kontakt z tymi, z którymi przed wielu laty chodził do szkoły, grał w teatrze, wędrował po górach czy pływał kajakiem. Jako ksiądz nie założył własnej rodziny, ale był tak blisko drugich, że stawał się dla nich wujkiem, bratem, ojcem. Jest znamienne, że ludzie gromadzący się wokół niego początkowo określali siebie jako „rodzinka”, dopiero potem przyjęła się ostatecznie nazwa „środowisko”. O formacji zaś tej grupy wzrastającej przy ks. Wojtyle może coś powiedzieć fakt, że niedługo po wyborze nowego papieża w mieszkaniu jednej z osób należących do „Środowiska” obok wiszącej od dawna fotografii Jana Pawła II pojawiła się świeża fotografia Benedykta XVI. Osoba ta przyjmowała z ciężkim sercem odejście mistrza, ale nie miała cienia wątpliwości: Wujek by sobie tego życzył. Ojca Świętego cechowała zawsze ogromna empatia, wrażliwość na 
drugiego człowieka. Kiedy ks. Malińskiemu przebywającemu na studiach w Rzymie zmarł brat, co przeżywał tym boleśniej, że z powodu ówczesnej sytuacji politycznej w Polsce nie mógł nawet pojechać na jego pogrzeb, abp Wojtyła uścisnął go serdecznie, bolejąc razem z nim jak po stracie własnego brata. Z czasem wspólnota wokół Papieża coraz bardziej się powiększała, dziś można powiedzieć, że objęła cały świat. Nie było chyba człowieka, który nie zostałby poruszony jego odejściem, a przy jego trumnie zgromadzili się przedstawiciele prawie wszystkich państw i religii oraz ważniejszych instytucji. Świadczy to wymownie o sile i bogactwie jego człowieczeństwa.

Wobec takiej wielkości spontanicznie rodzi się pytanie, w jaki sposób Papież kształtował swoje człowieczeństwo, przy pomocy jakich środków? Dla większości ludzi, którzy nie mogli obserwować z bliska jego stylu życia, niełatwo było je wychwycić, bo Ojciec Święty nie mówił wiele o nich, nie obnosił się ze swoimi metodami w pracy nad sobą. Dopiero w ostatnich latach, zresztą na prośbę innych, odsłonił nieco swój „warsztat”. I okazało się, że ten „warsztat” jest niezwykle prosty, chociaż bardzo wymagający.

Źródłem, które go inspirowało i umacniało, była w pierwszym rzędzie modlitwa, bardzo intensywna, głęboka, regularna. Jan Paweł II był mężem modlitwy. Zawsze uważał ją za podstawową sprawę w życiu, a kiedy został papieżem, mówił, że modlitwa jest jego najważniejszym zadaniem. Po wyborze na stolicę Piotrową w pierwszą podróż poza Rzym udał się do pobliskiej miejscowości górskiej Mentorelli, gdzie bywał wcześniej wiele razy, aby w ciszy małego sanktuarium modlić się przed obrazem Matki Bożej (kard. Zenon Grocholewski). Jak bardzo pilnował modlitwy, świadczy pytanie skierowane do abpa Stanisława Dziwisza tuż po wybudzeniu się z narkozy, pod którą był operowany po zamachu: Czy odmówiłem kompletę? Ojciec Święty potrafił zagłębić się na dłuższy czas w kontemplację, także w obecności innych, zapominając o całym świecie, ale korzystał też z tradycyjnych formuł, jak litanie, gorzkie żale czy droga krzyżowa. Archaiczna szata tych modlitw nie przeszkadzała mu w docieraniu do ich głębokich treści. Zwykł je dołączać np. w dziękczynieniu po mszy świętej jako tzw. „ogonki” według określenia pracujących przy nim Sióstr. Jednocześnie chętnie i z pożytkiem włączał się w modlitwę wspólną zarówno małych grup, jak i niezliczonych rzesz. Papież czerpał też wiele z sakramentów. Już w młodości często uczestniczył w Eucharystii i korzystał z sakramentu pokuty, solidnie się do nich przygotowując i bardzo głęboko je przeżywając. Jego sposób sprawowania Najświętszej Ofiary uderzał każdego uczestnika, pozostawiał w nim niezatarte wrażenie. Ciągle powracał do chrztu, bierzmowania i kapłaństwa. Kilkakrotnie przyjął sakrament namaszczenia chorych. W sakramentach spotykał się z Chrystusem, wchodził w Jego misterium paschalne śmierci 
i zmartwychwstania, upodabniał się do Niego. Przeżywał w nich także rzeczywistość Kościoła, mistycznego Ciała Chrystusa, ludu Bożego, łącząc się z innymi ludźmi więzami, które wykraczały poza naturalne upodobania. Pomagała mu w tym wytrwała, medytacyjna lektura Pisma Świętego, które traktował jako słowo Boże rozświetlające mroki ludzkiej egzystencji i otwierające przed człowiekiem perspektywę wieczności. Wszystko oceniał w jego świetle, ono było ostatecznym kryterium. Kard. Achille Silvestrini, bliski współpracownik Ojca Świętego w Watykanie, wyznał, że na koniec każdej rozmowy, po podjęciu każdej decyzji Papież pytał zawsze: Czy to będzie zgodne z Ewangelią?

Wizję wiary łączył Ojciec Święty z solidnymi studiami w różnych dziedzinach: literatura, filozofia, teologia. Dużo czytał, chociaż - jak sam przyznał - nie był typem encyklopedysty, nad oczytanie przedkładał własne myślenie. Nie bał się pytań, które przynosi życie, sam je stawiał i szukał na nie odpowiedzi. Podejmował aktualne problemy, nurtujące jego i innych, pełnił posługę myślenia. Zawsze chciał dotrzeć do istoty rzeczy, poznać rzetelnie prawdę, która rodziła w nim radość i dawała mu wolność. Czynił to nie tylko w pojedynkę, ale także wespół z innymi. Korzystał z ich dorobku, brał udział w dyskusjach, rozmawiał z nimi na ważkie tematy, chciał znać ich opinie. Stąd spotkania z naukowcami i ze studentami w Krakowie, w Lublinie, w Rzymie, w Castel Gandolfo. Bywało, że kiedy ktoś opublikował coś ciekawego, zapraszał go na wędrówkę, by w jej trakcie porozmawiać na temat nowej pracy (tak było po doktoracie ks. Edwarda Stańka). Już jako papież prosił do siebie naukowców z Polski i nie tylko, by zaznajomić się z ich osiągnięciami (tak było, gdy ks. Andrzej Szostek opublikował coś nowego z etyki). Papież podjął wszystkie główne problemy współczesności, przemyślał je i przedstawił swój punkt widzenia w licznych publikacjach. Nie przyjmował niczego tylko dlatego, że jakiś autorytet stał za tym, ale próbował zgłębić powody danego stanowiska. Gdy dziennikarze pytali go, czy nie stawia ludziom zbyt wielkich wymagań, odpowiadał, że sam zadaje sobie również to pytanie, ale nie może postępować inaczej, bo Bóg jest jeszcze bardziej wymagający, zawsze w imię godności człowieka, którego stworzył na swój obraz. Jak bardzo przemyślane teksty wychodziły spod jego pióra i jak dojrzałe były jego inicjatywy i decyzje, świadczy fakt, że nie musiał niczego odwoływać czy prostować, a przecież pozostawił po sobie 85 tys. zapisanych stron (samo przeczytanie tej spuścizny jest prawie niemożliwością, a co dopiero napisanie tego wszystkiego, nawet jeśli autorstwo Papieża ograniczało się w niektórych przypadkach tylko do sugestii) i przeprowadził wiele ważnych spraw, niekiedy bardzo trudnych, skomplikowanych, kontrowersyjnych. Po latach musieli przyznać mu rację nawet ci, którzy się z nim 
nie zgadzali, uważali go za utopistę (jak pewien filozof włoski, któremu słowa Papieża o dwóch płucach Europy wydawały się zupełnie nierealne, a przecież w krótkim czasie stały się rzeczywistością) lub wręcz zwalczali go (jak np. Wojciech Jaruzelski). Światło wiary w połączeniu z ludzką mądrością czyniło go prorokiem naszych czasów, sprawiało, że widział głębiej i dalej niż inni. Dlatego mógł przekonywać z całą mocą, że świat nie musi być taki, jakim go uczyniliśmy, że możliwe są zmiany i integralny rozwój zgodny z zamysłem Bożym. Wiele z tych zmian dokonało się jeszcze za jego życia, potwierdzając słuszność jego przewidywań!

Cokolwiek Papież robił, angażował się w to całkowicie, zabierał się bez ociągania do pracy i doprowadzał ją do końca. Znakomicie organizował sobie czas i wykorzystywał każdą chwilę. Lubił kontakt, rozmowę z drugim człowiekiem, ale nie trwonił czasu na banały, nie zajmował się błahostkami. Kiedy miał do wykonania jakąś pracę, przepraszał rozmówcę i zabierał się do dzieła. Stąd lampka i stolik w jego biskupim samochodzie. Pracował również w pociągu czy samolocie: modlił się, czytał, myślał, pisał. W czasie podróży pociągiem z Krakowa do Warszawy - wspomina bp Tadeusz Pieronek - rozmawiał chwilę tylko na początku drogi i potem pod jej koniec; gdy zbliżaliśmy się do stolicy, wypytywał o szczegóły spotkania, na które jechaliśmy. Poza tym cały czas był zajęty modlitwą i lekturą. Innym razem, podczas powrotu samolotem z kolejnej pielgrzymki, gdy osoba towarzysząca Papieżowi wyrażała zdumienie, że nie podziwia wspaniałych widoków, odparł, że musi przygotować rozważanie na „Anioł Pański” w najbliższą niedzielę. Ojciec Święty bardzo lubił piękne widoki i cenił sobie kontakty z ludźmi, ale kontrolował się, aby nie być zagarniętym przez przyjemną chwilę. Nie był niewolnikiem sytuacji ani ludzi, potrafił być sam. Uczestnicy spotkań z nim nieraz zapewne chcieli, by pozostał z nimi dłużej, on jednak był do dyspozycji drugich na tyle, na ile pozwalał mu harmonogram zajęć. Jednak w razie konieczności przedłużał rozmowę nawet poza zaplanowany czas, przez co nierzadko się spóźniał. Gdy jeszcze w okresie krakowskim proboszcz wizytowanej parafii, z którym jechał furmanką odwiedzić chorego, nie pozwolił mu pogrążyć się w lekturze, bo chciał porozmawiać ze swoim biskupem, nie oponował, spełnił jego pragnienie. Zawsze jednak starał się, by kontakty z ludźmi nie przeszkadzały mu w wypełnianiu innych obowiązków. Miał ich wiele, a były one w istocie jedną wielką służbą człowiekowi w diecezji, ojczyźnie, Kościele powszechnym. Musiał więc wyważać, by nie być bardziej z jednymi ludźmi kosztem innych i by zostało mu coś czasu na modlitwę, refleksję i odpoczynek.

Jan Paweł II był wierny i dokładny (ale nie drobiazgowy) w małych rzeczach, dostrzegał w nich wielkość, niezwykłość. Znajdował zawsze coś 
interesującego nawet w sprawach, które innych nużyły i męczyły. Z entuzjazmem wspominał choćby wykłady z gramatyki opisowej czy historycznej języka polskiego na Uniwersytecie Jagiellońskim, które pomagały mu zobaczyć, jak rodziły się i ewoluowały słowa, dotknąć ich tajemnicy, magii, mistyki (por. Dar i Tajemnica, s. 10-11). A przecież wiadomo, że nie ma nic bardziej „suchego” od gramatyk! Podobnie było z wizytacjami parafii rzymskich. Jest ich ponad trzysta w Wiecznym Mieście i Papież odwiedził je prawie wszystkie. Wizytacje odbywały się według ustalonego programu. Pierwsze mogły być ciekawe, ubogacające, natomiast przy następnych łatwo było wpaść w rutynę i znużyć się. Dla Papieża każda z tych wizyt była interesująca i niepowtarzalna. Dawała okazję do spotkania żywego Kościoła, duszpasterzy i wiernych, z których każdy to dla niego odrębny, bogaty świat. Dlatego przygotowywał się do nich sumiennie i przeprowadzał je $\mathrm{z}$ oddaniem (ks. Adam Boniecki).

Niezwykłość w rzeczach zwykłych dostrzegał Papież dzięki wrodzonej inteligencji i ogromnej przenikliwości. Jego świeżość spojrzenia, zachwyt, zdumienie nad rzeczywistością rodziły się jednak nade wszystko z miłości. To ona mu wszystko wyjaśniała i prowadziła w głąb tajemnicy świata. Ojciec Święty odkrył, że cała rzeczywistość zanurzona jest w miłości Boga. Sam czuł się nią zewsząd ogarnięty. O tej miłości mówiło mu słowo Boże, znaki sakramentalne, ale także ludzie i cała przyroda, każde stworzenie. Dostrzegał w nich odblask mądrości i piękna Boga. Dlatego rozpromieniał się na widok dziecka, cieszył się ze spotkań z młodymi, dostrzegał godność ludzką także w osobie zniedołężniałej i schorowanej. Człowiek był dla niego godzien najwyższego szacunku, gotów był przed nim uklęknąć i ucałować mu stopy, jak czynił to w każdy Wielki Czwartek. Zgłębiając tajemnicę człowieka, która go tak fascynowała, zobaczył, że prowadzi ona do tajemnicy Chrystusa i w niej dopiero się rozwiązuje (por. homilia w Warszawie, 2 czerwca 1979). Z podobnym nastawieniem podchodził Papież do świata materialnego. Kontemplował w nim cud istnienia i dotykał samego Stwórcy, źródła wszelkiego bytu. Kiedy w czasie jednego z wypadów poza Rzym natknął się na strumień, zatrzymał się nad nim i przez godzinę trwał w zadumie (ks. Tadeusz Styczeń). Również w czasie spaceru w Tatrach podczas pielgrzymki do Polski Papież przystanął dłuższą chwilę nad potokiem, a na koniec dotknął dłonią wody i przeżegnał się (kard. Franciszek Macharski; por. Tryptyk rzymski). Całe życie Papieża było odpowiedzią na miłość Boga, spłacaniem długu wdzięczności. Wszystko, co robił, robił dla Boga, z miłości do Niego. Miłość stanowiła najgłębszą motywację jego poczynań, popychała do tego, by się trudzić, wykorzystywać każdą minutę. To ona sprawiała, że nie czuł się znudzony ani zmęczony. Swą miłością obejmował nie tylko 
Boga, ale także i ludzi, każdego człowieka. Był dla wszystkich ojcem i to ojcem dobrym, który daje całego siebie, ale umie przy tym zachować odpowiedni dystans, nie narzuca się, nikogo nie zniewala. Znajdował zawsze piękny, naturalny sposób dla wyrażenia swej miłości. To ważne, bo wielu ludzi jest dobrych, ale nie wszyscy umieją to odpowiednio i przejrzyście uzewnętrznić. Jan Paweł II był wiarygodnym świadkiem miłości Boga, na wzór której ukształtował swoją miłość. Przesycony nią, promieniował ciepłem, radością, pokojem, spełnieniem, oddziałując mocno na drugich.

Posiadał niezwykłą władzę nad drugimi, także po śmierci - napisał jeden z dzienników niemieckich na widok tłumów ciągnących do Watykanu. Władza ta płynęła właśnie z miłości. Jest ona z pozoru krucha, w rzeczywistości najmocniejsza i najbardziej uniwersalna. Dywizje, o które pytał Stalin, okazują się wobec niej słabe, nieskuteczne. Promieniująca miłość Papieża podbijała i przemieniała serca. Ludzie odwzajemniali jego miłość, w chwili jego odejścia do Pana była to istna eksplozja uczuć, i to niezależnie od narodowości czy religii. Jego postawa inspirowała wielu do pojednania, w jego obecności stawało się ono łatwiejsze. Tak było od dawna. Kard. Andrzej Maria Deskur podpatrzył metodę jednania drugich stosowaną przez kard. Wojtyłę. Była prosta: sadzał poróżnionych ludzi obok siebie przy stole i pozwalał im rozmawiać; po niedługim czasie adwersarze sami dochodzili do wniosku, że w gruncie rzeczy ich opinie niewiele się różnią. Przy trumnie Papieża spotkali się po raz pierwszy prezydenci Izraela i Syrii, podali sobie ręce Lech Wałęsa i Aleksander Kwaśniewski. Również skłóceni kibice rywalizujących drużyn piłkarskich modlili się wspólnie w duchu pojednania. Niektóre z tych gestów dobrej woli były wprawdzie krótkotrwałe i płytkie, ale to pokazuje jedynie, jak niełatwo jest wspiąć się na takie wyżyny ducha i na nich się utrzymać. Na tym tle odznacza się jeszcze bardziej wielkość Papieża. Wielu chciałoby ją osiągnąć, ale zapomina, że jej prawdziwym źródłem jest więź z Bogiem, a droga - Ewangelia brana dosłownie i realizowana w codziennym życiu przy pomocy prostych środków, o których wspomnieliśmy: modlitwa, sakramenty, studium, praca, wykorzystanie czasu, wierność w małym... (kard. Miloslaw Vlk). Oznacza to ciągłe przeciwstawianie się słabościom, przekraczanie siebie, aby żyć wielkimi wartościami. To wiele kosztuje, czasem jawi się jako umieranie, zatracenie siebie. Za prawdziwą wielkością stoi zawsze ogromna łaska Boża i ogromny wysiłek człowieka, który jednak staje się paradoksalnie lekki (por. Mt 11, 30).

O Janie XXIII mówiono: „Papież dobry” (Papa buono), o Janie Pawle II natomiast mówi się w sposób bardziej zasadniczy: „człowiek dobry” (uomo buono). W naszym Papieżu bowiem objawiło się w stopniu niespotykanym samo człowieczeństwo, dlatego tak uniwersalny wpływ ma jego świadectwo, 
dotyka tego, co istotne w człowieku i wspólne wszystkim ludziom. Przeżywanie swego człowieczeństwa było w jego wypadku ważniejsze niż wszystkie role, które przyszło mu w życiu wypełniać. Pełny kształt człowieczeństwa to główne dzieło jego wielostronnej twórczości (por. przemówienie do świata kultury w Warszawie, 8 czerwca 1991). Oto prawdziwy człowiek! Tylko Bóg jest dobry - odpowiadał Jezus bogatemu młodzieńcowi (por. Mk 10,18). Jeśli mówimy o kimś „,dobry”, wskazujemy na jego ścisły związek z Bogiem - źródłem dobra. Taki człowiek jest też autentycznie wielki i święty. Człowiek jest w pełni człowiekiem, gdy żyje z Bogiem i w Bogu. Papież zdążał całe życie do Boga, idąc za Chrystusem i Jego Matką. Tego przede wszystkim możemy i powinniśmy uczyć się od niego. On będzie nam na pewno towarzyszył w tej wędrówce, pójdzie z nami, jak szedł przez lata swego pasterzowania w Krakowie i w Rzymie. Poprowadzi nas do miłości, pomoże odkryć, że jesteśmy zanurzeni w miłości Boga, na którą trzeba odpowiadać również miłością - do Boga, ludzi i całego stworzenia. Na tym polega być człowiekiem!

W życiu i posłudze Jana Pawła II spełniło się coś z przepowiedni Juliusza Słowackiego o słowiańskim papieżu, który poruszy świat i zapali go miłością. I jakaś szczególna rola Polski w tym się również ujawniła. Intuicje romantyzmu polskiego, którymi Papież karmił się od młodości, nie były więc chyba czystymi mrzonkami, które czas rozwiewa niczym poranną mgłę. Wydają się płynąć z Ewangelii i zawierać coś istotnego i nieprzemijającego, mogą prowadzić do autentycznego człowieczeństwa. Polskość w swym najlepszym wyrazie jest na wskroś ewangeliczna. Nie trzeba się jej wstydzić, tak jak nie wstydził się jej Ojciec Święty. On jest jej owocem, za który dziękują nam dzisiaj inne narody.

Kraków

KS. STANISEAW WRONKA

\section{Riassunto}

\section{Giovanni Paolo II - l'uomo buono}

Landare di Giovanni Paolo II alla casa del Padre ha toccato profondamente tutti, credenti e non credenti. Il modo in cui il Papa viveva i suoi ultimi giorni, segnati dalla sofferenza, la sua pasqua dalla morte alla vita in Dio, ha confermato definitivamente la sua grandezza. Agli occhi del mondo è sfavillata la sua bella umanità e allo stesso tempo si è aperto unenorme e doloroso vuoto. La vicenda dell'uomo rassomiglia a quella di un albero: si può valutarne bene la grandezza, salute e posto nel paesaggio solo quando è abbattuto.

Lumanità del Santo Padre era tutta tessuta dei valori massimi di verità, libertà, amore... Il Papa li realizzava con radicalismo e coraggio che però sapeva unire alla mitezza e rispetto verso gli altri. Questa difficile sintesi testimonia il suo genio morale. Il fondamento dell'umanità di Giovanni Paolo II era la fede in Dio che rafforza le naturali capacità dell'uomo e permette di unire tutti gli elementi della realtà umana, inclusa la sofferenza e morte, in un armonioso insieme. Il legame con Dio non lo separava dagli uomini, ma lo apriva ancor 
di più a loro. Infatti, accanto a lui si radunavano sia giovani che adulti ed egli li univa sulla base dei valori che riconosceva. Col passare del tempo, la comunità attorno a lui aumentava, nel giorno del suo funerale abbracciava pressoché tutto il mondo. Ciò dimostra la giustezza dell'antropologia evangelica alla cui luce costruiva tutta la sua vita.

I mezzi con cui il Santo Padre foggiava la sua umanità erano semplici, ma esigenti. La fonte della forza e della luce costituiva per lui soprattutto una fervida e costante preghiera, frequente partecipazione ai sacramenti e sistematica meditazione sulla Parola di Dio. A queste pratiche religiose univa un solido studio delle diverse materie: letteratura, filosofia, teologia. Con passione perseguiva la verità, voleva raggiungere l'essenza delle cose e fenomeni, trattava le questioni del tempo, confrontava i risultati delle sue riflessioni con le opinioni degli scienziati, artisti, politici. La luce della fede unita alla sapienza umana lo faceva un profeta dei nostri tempi che vedeva più lontano e più profondamente e influiva in modo efficace sul corso della storia. Poteva operare così molto grazie alla sua enorme laboriosità, sfruttamento di ogni istante e fedeltà nel poco.

In verità per il Papa niente era di poco valore, egli scorgeva in tutto la straordinarietà, dappertutto scopriva con meraviglia le tracce della bellezza, sapienza e amore di Dio - nell'uomo, negli eventi, nella natura. Voleva rispondere a questo amore anche con amore con il quale abbracciava Dio, uomini e ogni creatura. L'amore faceva sì che non si sentisse mai annoiato né stanco e che esercitasse così forte influsso sugli altri. La gente si affezionava a lui, ricambiando il suo amore paterno e cercava di tramandarlo oltre, tentando perfino di riconciliarsi con i nemici. Infatti, è difficile resistere al potere dell'autentico amore!

Di Giovanni XXIII si diceva: „Papa buono”, invece di Giovanni Paolo II si dice in modo più principale: „uomo buono”, poiché in lui si è manifestata nella misura rarissima la stessa umanità, la sua forma piena. Essere buono vuol dire essere vicino a Dio che come unico è veramente buono e fonte del bene. Dunque l'uomo buono è anche santo e grande. Tale era Giovanni Paolo II, perché cercava sempre di stare vicino a Dio, seguendo Cristo e la sua Madre. In questo cammino lo aiutavano la tradizione e la cultura polacca che nelle loro espressioni più alte sono fino in fondo evangeliche. 